disease but that they already have the disease has been difficult. Hence, most of the problems encountered have been in the clinical and counselling sphere rather than laboratory related.

In general most of the reported studies of predictive testing have closely followed the principles laid out in the guidelines. Perhaps inevitably some recommendations have not been fulfilled, notably that testing should be available equally to people of all regions and from all countries. Many European countries have not begun testing, while in the United States problems of continued funding have led at least one of the original regional centres to stop offering the test. In Canada a nationwide network of testing centres has been set up, with a common set of procedures and regular communication among units. ${ }^{16} \mathrm{~A}$ comparable network is now evolving in Britain: there are now around 12 such centres, all following a similar pattern of testing, counselling, and support, with a coordinating group and a common core protocol for service use.

These developments should allow continued audit of the process of predictive testing for Huntington's disease and will eventually provide information on how this process has affected the lives of those who have undergone testing. New advances - notably the detection of the specific mutation(s) for the disorder (which is likely in the near future)-will be able to be incorporated into the testing framework, and we should learn much that is relevant to prediction in other disorders. Whether the system that has evolved will be able to continue and develop will also be a test for the changes proposed in the NHS. So far, as with other developments in medical genetics, the system has proved flexible and effective; we hope that it will continue to allow the steady evolution of preventive measures such as testing for Huntington's disease and other serious genetic disorders.

PETER S HARPER Professor of Medical Genetics MICHAEL J MORRIS Research Senior Registrar

AUDREY TYLER

Institute of Medical Genetics,

University of Wales College of Medicine, Cardiff CF4 4XN Genetic Fieldworker (Research)

1 Gusella JF, Wexler NS, Conneally PM, et al. A polymorphic DNA marker genefically linked to Huntington's disease. Nature 1983;306:234-8.

2 Thomas S. Ethics of a predictive test for Huntington's chorea. Br Med f 1982;284:1383-9.

3 Brandt J, Quaid KA, Folstein SE, et al. Presymptomatic diagnosis of delayed-onset disease with linked DNA markers. IAMA 1989;261:3108-14.

4 Brock DJH, Mennie M, Curtis A, et al. Predictive testing for Huntington's disease with linked DNA markers. Lancet 1989;ii:463-6.

Wiggins S. Early follow-up of persons participating in the Canadian national collaborative study of predictive testing for Huntington's disease. Am f Hum Genet 1989;45 (suppl):A282.

6 World Federation of Neurology Research Group on Huntington's Chorea. Ethical issues policy orld Federation of Neurology Research Group on Huntington's Chorea. Ethical issues policy statement on Huntington's disease molecular genetics predictive test. $\mathcal{F}$ Med Genet 1990;27:34-8. watid Federation of Neurology Research Group on Huntington's Chorea. Ethical issues policy
statent Huntington's disease molecular genetics predictive test. F Neurol Sci 1990;94:327-

8 Tyler A, Morris M. Symposium on predictive testing on Huntington's disease. $\mathcal{J}$ Med Ethics $1990 ; 16: 41-2$.

9 Morris M, Tyler A. World Federation of Neurology Research Group on Huntington's disease, Vancouver, July, 1998. F Med Genet 1990;27:211-2.

10 Morris M. Huntington's disease: presymptomatic testing. Current Opinion in Neurology and Neurosurgery (in press).

11 Quaid KA, Brandt J, Folstein SE. The decision to be tested for Huntington's disease. FAMA 1987;257:3362.

12 Craufurd D, Dodge A, Kerzin-Storrar L, Harris R. Uptake of presymptomatic predictive testing for Huntington's disease. Lancet 1989;ii:603-5.

3 Morris MJ, Tyler A, Lazarou L, Meredith L, Harper PS. Problems in genetic prediction for Huntington's disease. Lancet 1989;ii:601-3.

14 Morris M, Tyler A, Harper PS. Adoption and genetic prediction for Huntington's disease. Lancet 1988:ii:1069-70.

15 Bloch M, Hayden MR. Predictive testing for Huntington's disease in childhood: challenges and implications. Am f Hum Genet 1990;46:1-4.

16 Dayton S. Canada pioneers national screening for Huntington's disease. New Scientist 1988; Sep 22:26.

\title{
Pelvic inflammatory disease
}

\section{A sexually transmitted disease with potentially serious sequels that is often treated poorly}

Pelvic inflammatory disease in women is inflammation of the upper genital tract. The term embraces endometritis, salpingitis, and salpingo-oophoritis, together with spread to the peritoneum as peritonitis and along the paracolic gutters to cause the Fitzhugh-Curtis syndrome of perihepatitis. It is virtually always due to ascending infection through the cavities of the cervix, uterus, and fallopian tubes; on histological examination the endometrium is always affected. ${ }^{12}$

The natural barrier to pelvic infection is the cervix, where a downward flow of the mucus and the action of cilia are augmented by the production of a lysozyme. Aided by the presence of cervically secreted IgA the lysozome hydrolyses the peptiglycan links of micro-organisms, allowing osmotic destruction. ${ }^{3}$ The cervical barrier may be compromised after miscarriage, abortion, childbirth, cervical surgery, and in the presence of an intrauterine contraceptive device. The risk of pelvic inflammatory disease after termination of pregnancy is of the order of $2 \%$, but this increases up to 10 -fold in women with asymptomatic sexually transmitted diseases. ${ }^{+}$Few centres, however, screen women undergoing termination for asymptomatic infections or give prophylactic antibioticswhich seem to be effective in these circumstances. ${ }^{+}$The risk of pelvic inflammatory disease in women fitted with intrauterine contraceptive devices has probably been overstated. There is a transient risk at the time of insertion, ${ }^{5}$ but the increased relative risk (approximately $1 \cdot 0-3 \cdot 0$ ) is probably due to a diagnosis bias. ${ }^{6}$
The most common cause of pelvic inflammatory disease is coitus. Many organisms that alone do not seem to be sufficiently mobile may ascend the genital tract on the back of spermatozoa. These include Neisseria gonorrhoeae, Ureaplasma urealyticum, ${ }^{8}$ Chlamydia trachomatis, ${ }^{9}$ and several anaerobic species. ${ }^{10}$ The uterine contractions that accompany orgasm may also possibly draw spermatozoa and microorganisms into the uterus. ${ }^{11}$

Pelvic inflammatory disease has undoubtedly become more common. In the 1960s gonorrhoea seemed to be the main cause, and over a period of 20 years this infection became at least three times more frequent in most parts of the world. ${ }^{12} 13$ Up to one fifth of women infected with gonorrhoea developed pelvic inflammatory disease. ${ }^{14}$ In the 1980 s $C$ trachomatis has become a more important cause; it now accounts for up to half of the cases of pelvic inflammatory disease in Europe ${ }^{15}$ and two fifths of the women treated in hospital in the United States. ${ }^{16}$ Chlamydial disease (as judged by the rate of non-gonococcal urethritis in men) has increased fourfold in the past 30 years in England and Wales. ${ }^{12}{ }^{17}$ Overall, sexually transmitted diseases now underlie about three quarters of all cases of pelvic inflammatory disease. In industrialised countries the incidence of pelvic inflammatory disease is now 10 to 13 per 1000 women of reproductive age, with the peak incidence of 20 per 1000 occurring in those aged 15-24 years. ${ }^{18} 19$

Despite some problems of definition, ${ }^{18}$ the varying criteria for diagnosis in published reports, and follow up that is often 
inadequate there is clear evidence that the sequelae of pelvic inflammatory disease are both serious and common. A single episode of the disease is associated with six to 10 times the risk of a new episode,${ }^{19} 20$ a one in six chance of tubal infertility ${ }^{21}$ (and the risk doubles for each subsequent attack), a sevenfold increase in the risk of ectopic pregnancy, ${ }^{22} \mathrm{a}$ one in five chance of chronic pelvic pain, ${ }^{23}$ a two in five chance of deep dyspareunia, and a four in five chance of menstrual disturbance. ${ }^{23}$ Early diagnosis and appropriate treatment can prevent these complications. ${ }^{22}$

The diagnosis of pelvic inflammatory disease made on clinical grounds by trained gynaecologists (who knew that they were under study) was incorrect in $35 \%$ of cases when checked by subsequent laparoscopy. ${ }^{24}$ All too often the diagnosis tends to be a dustbin for all sorts of non-specific lower abdominal pain in young women. Strict clinical and laboratory findings have been proposed, together with a clinical grading system of severity, ${ }^{25}$ and the use of these would not only improve diagnosis but would also form the basis for comparative work. Bacteriological swabs from the urethra and the cervix should be stained immediately by Gram's method and examined for pus and gonococci (as well as being sent for culture). Although this happens in every genitourinary clinic it rarely, if ever, occurs in settings where gynaecologists see women. Cervical swabs should be used to collect endothelial cells and an immunofluorescent monoclonal antibody test used to look for $C$ trachomatis. Swabs from the rectum and oropharynx rarely, if ever, add useful evidence to vaginal and urethral swabs correctly collected and may antagonise patients. This is not the case, however, with examination of the woman's sexual partnerpositive results are often obtained in men. Partners of women with non-specific pelvic inflammatory disease can be shown to have gonorrhoea in about $15 \%$ of cases ${ }^{26}$ and be infected with chlamydia in $12 \%$ of cases. ${ }^{27}$ Again, examination and follow up of partners is standard practice in genitourinary clinics but is not part of gynaecological practice.

There is a strong case for performing a laparoscopy to confirm the diagnosis. ${ }^{2+}$ It not only excludes other disorders but allows collection of specimens of fluid from the pouch of Douglas and the fallopian tubes. These greatly improve the accuracy of bacteriological diagnosis. ${ }^{28}$ Diagnostic laparoscopy seems unacceptable to most gynaecologists, however, despite the low risk of complications from the procedure.$^{29}$ Instead, the most common approach to treatment is a trial of treatment with antibiotics, and laparoscopy is reserved for those women who do not respond to treatment or who have a clinically detectable mass. This policy makes little sense, for only $32 \%$ of clinical masses are confirmed at laparoscopy and $9 \%$ of masses seen at laparoscopy are not clinically apparent. ${ }^{30}$

Arguments persist as to whether pelvic inflammatory disease is caused by a single organism ${ }^{28}$ or multiple organisms. ${ }^{31}$ Probably primary infections with $N$ gonorrhoea or $C$ trachomatis, or both, allow opportunist infection with both aerobic and anaerobic bacteria. This finding, together with analysis of the antibiotics required to cover the wide variety of organisms reported, strongly suggests that treatment with single agents is likely to be inadequate. ${ }^{32}$

The optimum treatment for acute pelvic inflammatory disease requires admission to hospital to allow laparoscopic diagnosis, frequent observations, and treatment with parenteral antibiotics. This should include a single dose of ampicillin and probenecid (against gonorrhoea), a broad spectrum antibiotic effective against Gram negative organisms (such as gentamicin or a second generation cephalosporin) for one week, metronidazole (against anaerobes) for two weeks, and at least a two week follow up course of doxycycline or erythromycin to prevent persistence of chlamydia. ${ }^{16}$ In Britain women with pelvic inflammatory disease are usually admitted to hospital only if they have systemic symptoms or have a palpable pelvic mass, and they are commonly treated with a single agent. If circumstances suggest that a patient with abdominal pain has mild pelvic inflammatory disease it may be appropriate to treat her with oral tetracyclines, co-trimoxazole, and metronidazole (which should cover more than $90 \%$ of organisms) and review her in two to three days. If she is not definitely improved then admission for laparoscopy should be arranged. These treatments should be open to review if culture shows a specific organism.

Pelvic inflammatory disease is, then, a common infection of increasing prevalence, especially since 1960. It is largely a sexually transmitted disease with potentially serious sequelae and is usually managed badly by doctors with little interest in the condition. Gynaecologists need radically to change their current management, perhaps with more active cooperation from genitourinary physicians.

Senior Lecturer in Obstetrics and Gynaecology,

J MALCOLM PEARCE

Senior Lecturer in Obstetrics and Gynat
St George's Hospital Medical School,

London SW $170 \mathrm{RE}$

Westrom L. Incidence, prevalence and trends of acute pelvic inflammatory disease and it consequences in industrialised countries. Am f Obstet Gynecol 1980;138:880-92.

2 Heinonen PK, Teisala K, Punnonen R, Miettenen A, Lehtinen M, Paavonen J. Anatomic sites of upper genital tract infection. Obstet Gynecol 1985;66:384-90.

Cohen MS, Black JR, Proctor RA, Sparling PF. Host defences in the vaginal mucosa. In Mardh P-A, Taylor-Robinson D, eds. Bacterial vaginosis. Stockholm: Almquist and Wiksell International, 1984:13-22.

4 Savage W. Therapeutic abortion. In: Turnbull AC, Chamberlain GVP, eds. Obstetrics. Edinburgh: Churchill Livingstone, 1989:430-1

5 Mishell DR, Bell JH, Good RG, Moyer DL. The intrauterine device: a bacteriologic study of the endometrial cavity. Am f Obstet Gynecol 1966;96:119-23.

6 Kessel E. Pelvic inflammatory disease with intrauterine device use: a reassessment. Fertil Steri 1989;51:1-11.

7 Gomez CI, Stenback WA, James AN, Criswell BS, Williams RP. Attachment of N gonorrhoeae to human sperm. British fournal of Venereal Diseases 1979;55:245-55

8 Gnarpe H, Friberg H. T-mycoplasmas on spermatozoa and infertility. Nature 1973;245:97-8.

9 Wolner-Hanssen P, Mardh P-A, Moller B, Westrom L. Endometrial infection in women with chlamydial salpingitis. Fournal of Sexually Transmitted Diseases 1982;9:84-8.

10 Keith LG, Berger GS, Edelman DA, et al. On the causation of pelvic inflammatory disease. Am f Obstet Gynecol 1984;149:215-23.

11 Fox CA, Wolff HS, Baker JA. Measurement of intravaginal and intrauterine pressures during human coitus by radio-telemetry. $\mathcal{F}$ Reprod Fertil 1970;22:243-51.

12 Aral SO, Holmes KK. Epidemiology of sexually transmitted disease. In: Holmes KK, Mardh P-A, Sparling PF, Wiesner PJ, eds. Sexually transmitted diseases. New York: McGraw-Hill, 1984 $127-41$.

13 Sweet RL, Gibbs RS. Sexually transmitted diseases. In: Sweet RL, Gibbs RS, eds. Infectious diseases of the female genital tract. Baltimore: Williams and Wilkins, 1985:17-52.

14 Westrom L, Svensson L, Wolner-Hanssen P, Mardh P-A. Chlamydial and gonococcal infections in a defined population of women. Scand F Infect Dis /Suppl] 1982;32:157-62.

15 Westrom L, Mardh P-A. Chlamydial salpingitis. Br Med Bull 1983;39:145-50.

16 Sweet RL, Schachter J, Robbie MO. Failure of beta lactam antibiotics to Chlamydia trachomatis in the endometrium despite clinical cure of acute salpingitis. JAMA 1983;250:2641-5.

17 Catterall RD. The situation of gonococcal and non-gonococcal infections in the United Kingdom. In: Danielsson D, Juhlin L, Mardh P-A, eds. Genital infections and their complications. Stockholm: Almquist and Wiksell, 1975:5-13.

18 Centers for Disease Control. Pelvic inflammatory disease: United States. MMWR 1980;28:605-7.

19 World Health Organisation. Non-gonococcal urethritis and other sexually transmitted diseases of public health importance. WHO Tech Rep Ser 1981;660:98-100.

20 Westrom L. Effect of acute pelvic inflammatory disease on fertility. Am $\mathcal{J}$ Obstet Gvnecol 1975;121:707-13.

21 Westrom L. Long term consequences of pelvic inflammatory disease. In: Hare MJ, ed. Genital tract infection in women. Edinburgh: Churchill Livingstone, 1989:350-67.

22 Urquhart J. Effect of the venereal disease epidemic on the incidence of ectopic pregnancyimplications for the evaluation of contraceptives. Contraception 1979;19:455-80.

23 Adler MW, Belsy EM, O'Connor BH. Morbidity associated with pelvic inflammatory disease. British fournal of Venereal Diseases 1982;58:151-7.

24 Jacobson L, Westrom L. Objectivised diagnosis of acute pelvic inflammatory disease. Am $\mathcal{J}$ Obstet Gynecol 1984;105:1088-98.

25 Hager WD, Eschenmbach DA, Speme MR, Sweet RL. Criteria for diagnosis and grading of salpingitis. Obstet Gynecol 1983;61:113-4.

26 Gilstrap LC, Herbert WNP, Cunningham FG, Hauth JC, Van Patten HG. Gonorrhoea screening in male consorts of women with pelvic infection. fAMA 1977;238:965-6.

27 Osser S, Persson K. Epidemiological and serodiagnostic aspects of chlamydial salpingitis. Obstet Gynecol 1982;59:206-9.

28 Mardh P-A, Ripa T, Svensson L, Westrom L. Chlamydia trachomatis infection in patients with acute salpingitis. N Engl f Med 1977;296:1377-9.

29 Chamberlain GVP, Carron-Brown J. Gynaecological laparoscopy. London: Royal College of Obstetricians and Gynaecologists, 1978 .

30 Lundberg WI, Wall JE, Mathers JE. Laparoscopy in evaluation of pelvic pain. Obstet Gynecol 1973;42:872-6.

31 Sweet RL, Mills J, Hadley KW, et al. Use of laparoscopy to determine the microbiological aetiology of acute salpingitis. Am $\mathcal{O}$ Obstet Gynecol 1979;134:68-74.

32 Bell TA, James JF. Computer assisted analysis of the therapy of acute salpingitis. Am $\mathcal{J}$ Obstet Gynecol 1980;138:1048-54. 